Vloedman, D. A. Jun., Berech, J. Jun., Jeffries, W. B. \& van Wagtendonk, W. J. (1957). J. gen. Microbiol. 16, 628-641

\title{
Carbohydrate Metabolism of Paramecium aurelia, Variety 4, Stock 47.8 (Sensitive)
}

\author{
By D. A. VLOEDMAN Jun.,* J. BERECH Jun., W. B. JEFFRIES $\dagger$ \\ AND W. J. VAN WAGTENDONK \\ Department of Zoology, Indiana University, Bloomington, Indiana, U.S.A.
}

SUMMARY: Homogenates of Paramecium aurelia, var. 4, stock 47.8 (sensitive), grown in axenic culture contain enzymes of the glycolytic, the citric acid cycle, and the pentosephosphate pathway. The presence of the following enzymes has been demonstrated: hexokinase, phosphoglucomutase, phosphohexoisomerase, aldolase, triosephosphate dehydrogenase, glucose-6-phosphate dehydrogenase, 6-phosphogluconic acid dehydrogenase, pentosephosphate isomerase, citric acid oxidase, isocitric acid dehydrogenase, $\alpha$-ketoglutaric acid dehydrogenase, succinic acid oxidase, malic acid dehydrogenase, glutamic acid dehydrogenase, fumarase, and acid phosphatase. The presence of phosphorylase, transaldolase and transketolase is indicated.

Studies on the metabolism of ciliates have been notably deficient in the investigation of the presence of the individual enzymes of the metabolic sequences. Most studies have been confined to adding compounds to media in which the protozoans were to be grown. Increased multiplication or an increased oxygen uptake measured in the conventional Warburg apparatus was taken to indicate that the compounds under investigation were metabolites. Humphrey \& Humphrey (1948) found that succinic acid would cause a twofold increase in the respiration of Paramecium caudatum. In studies on the utilization of carbohydrates by the same organism Geddes \& Humphrey (1951) established that glycogen, glucose, fructose, glucose-1-phosphate, glucose-6-phosphate and fructose-1:6-diphosphate were utilized. A few studies on the presence of enzymes of the electron transport system in Paramecium, notably cytochrome oxidase, have been made by Clark (1945) and Boell (1945), while Sato \& Tamiya (1937) demonstrated the presence of cytochromes c, a and b in Paramecium. Simonsen \& van Wagtendonk (1952) suggested that the respiration of killer stocks of $\boldsymbol{P}$. aurelia, which, unlike the respiration of sensitive stocks, is not inhibited by $\mathrm{KCN}$, may be almost entirely mediated by flavin systems. In a later study (Simonsen \& van Wagtendonk, 1956), the same authors reported the presence in killer cells of an active succinoxidase system which is absent, or present only in small concentrations in the sensitives. The metabolism of Tetrahymena pyriformis has been extensively studied and the presence of many enzymes involved in the various phases of carbohydrate metabolism has been established. This work has been reviewed by Seaman (1955).

* Present address: Department of Biochemistry, University of Miami Medical School, Coral Gables, Florida, U.S.A.

$\uparrow$ Present address: Department of Microscopic Anatomy, Medical College of Georgia, Augusta, Georgia, U.S.A. 
While many enzymic studies on the metabolism of Paramecium aurelia can be carried out in bacterized media, it is imperative for certain experiments of long duration involving homogenates that these be free from contaminants. With the advent of an axenic medium for $\boldsymbol{P}$. aurelia (van Wagtendonk, Conner, Miller \& Rao, 1953; Miller \& van Wagtendonk, 1956), an investigation of its carbohydrate metabolism became possible without the danger of interference by other organisms.

\section{METHODS}

Paramecium aurelia, var. 4, stock 47.8 (sensitive), was grown axenically in the medium given in Table 1 or in the medium described by Vloedman (1955). Large cultures were derived from cultures in test tubes by transferring to

Table 1. Composition of axenic medium for Paramecium aurelia

\begin{tabular}{|c|c|c|c|}
\hline Component & $\begin{array}{l}\text { Conen. } \\
(\mu \mathrm{g} . / \mathrm{ml} .)\end{array}$ & Component & $\begin{array}{l}\text { Concn. } \\
(\mu \mathrm{g} . / \mathrm{ml} .)\end{array}$ \\
\hline Vitamins & & Amino acids & \\
\hline Pantothenic acid & $2 \cdot 0$ & L-Arginine & 200 \\
\hline Nicotinamide & $\mathbf{2 \cdot 0}$ & L-Histidine & 100 \\
\hline Pyridoxal & $\mathbf{2 \cdot 0}$ & DL-Isoleucine & 300 \\
\hline Biotin & 0.03 & L-Leucine & 300 \\
\hline Riboflavin & $\mathbf{2} \cdot \mathbf{0}$ & L-Lysine & 250 \\
\hline Folic acid & $1 \cdot 0$ & DL-Methionine & 300 \\
\hline Thiamine & $6 \cdot 0$ & L-Phenylalanine & 150 \\
\hline Salts & & DL-Serine & 400 \\
\hline Sodium ethylencdinitrilotetraacetate & $10 \cdot 0$ & DL-Threonine & 300 \\
\hline $\mathrm{MgSO}_{4} \cdot 7 \mathrm{H}_{2} \mathrm{O}$ & $50 \cdot 0$ & L-Tryptophan & 100 \\
\hline $\mathrm{Fe}\left(\mathrm{NH}_{4}\right)_{2}\left(\mathrm{SO}_{4}\right)_{2} \cdot 6 \mathrm{H}_{2} \mathrm{O}$ & $\begin{array}{l}50 \cdot 0 \\
12 \cdot 5\end{array}$ & L-Tyrosine & 75 \\
\hline $\mathrm{MnCl}_{2} \cdot 4 \mathrm{H}_{2} \mathrm{O}$ & $0 \cdot 25$ & DL-Valine & 150 \\
\hline $\mathrm{ZnCl}_{2}$ & 0.03 & L-Alanine & $\mathbf{5 0}$ \\
\hline $\mathrm{CaCl}_{2} \cdot 2 \mathrm{H}_{2} \mathrm{O}$ & $25 \cdot 0$ & L-Aspartic acid & 100 \\
\hline $\mathrm{CuCl}_{2} \cdot 2 \mathrm{H}_{2} \mathrm{O}$ & $2 \cdot 5$ & Glycine & 50 \\
\hline $\mathrm{FeCl}_{3} \cdot 6 \mathrm{H}_{2} \mathrm{O}$ & $0 \cdot 63$ & L-Glutamic acid & 150 \\
\hline $\mathrm{K}_{2} \mathrm{HPO}_{4}$ & $500 \cdot 0$ & I-Proline & 100 \\
\hline $\mathrm{KH}_{2} \mathrm{PO}_{4}$ & $500 \cdot 0$ & \multicolumn{2}{|c|}{ Yeast fractions (mg./ml.) } \\
\hline Sodium acetate & $500 \cdot 0$ & Precipitate* & $3 \cdot 0$ \\
\hline Stigmasterol & $0 \cdot 2$ & & \\
\hline
\end{tabular}

* The precipitate was obtained from a water extract of yeast (Conner \& van Wagtendonk, 1953) by addition of an equal volume of acetone and centrifugation of the mixture (Conner \& van Wagtendonk, unpublished).

increasingly larger volumes, up to $500 \mathrm{ml}$. in a $3 \mathrm{l}$. Erlenmeyer flask. At maximum population density (5000-10,000 organisms/ml.), the organisms were harvested by filtering the culture through a sterile Berkefeld filter. Further concentration was obtained by electromigration through a sterile salt solution according to the procedure described by van Wagtendonk, Simonsen \& Zill (1952), followed by a final centrifugation at $850 \mathrm{~g}$ for $10 \mathrm{~min}$. The resulting pellet was suspended in a suitable amount of buffer, homogenized with the apparatus described by Katzberg (1950), a hand homogenizer of the PotterElvehjem type, or by exposure to ultra-sound in a $10 \mathrm{kc}$. oscillator (water 
cooled Raytheon), and made up to the desired volume with the same buffer. Cell-free extracts were prepared by centrifugation of the homogenates at $24,000 \mathrm{~g}$ in an angle centrifuge for $30 \mathrm{~min}$. The protein content of the homogenates and the cell-free extracts was determined according to the method of Gornall, Bardawill \& David (1949). In some instances the $\mathbf{N}$ content of the homogenates was determined with the micro-Kjeldahl method using the digestion mixture of Brüell, Holter, Linderstrøm-Lang \& Rozits (1947).

Reduction of 2,3,5-triphenyltetrazolium chloride (TTC) was used for the determination of dehydrogenases. The determinations were carried out in conical graduated centrifuge tubes $(15 \mathrm{ml}$.). The reaction mixture consisted of $0.5 \mathrm{ml}$. substrate at a suitable concentration; $0.1 \mathrm{ml} .0 .001 \%(\mathrm{w} / \mathrm{v})$ diphosphopyridine nucleotide (DPN, 65\% pure, Sigma); $0.1 \mathrm{ml}$. 0.05 M-cysteine; $0.1 \mathrm{ml} .0 .1 \mathrm{M}-\mathrm{MgCl}_{2} ; 0.5 \mathrm{ml} .0 .001 \%(\mathrm{w} / \mathrm{v})$ TTC; $0.5 \mathrm{ml}$. homogenate and 0.1 M-tris-(hydroxymethyl)-amino-methane (Tris) buffer to a final volume of 2-5 $\mathrm{ml}$, , depending upon the determination. The reaction mixture was incubated at $37^{\circ}$ for various lengths of time and the reaction stopped by the addition of $1 \mathrm{ml} .10 \%(\mathrm{w} / \mathrm{v})$ trichloroacetic acid (TCA). The resulting precipitate, consisting of protein and reduced and unreduced TTC, was spun down at $850 \mathrm{~g}$ in a refrigerated centrifuge. The supernatant fluid was poured off, and the pellet extracted twice with $2 \mathrm{ml}$. acetone. One $\mathrm{ml} .10 \%$ TCA was added to the second acetone extract. (The extraction of the precipitate with chloroformacetone as recommended by Green, Mii, Mahler \& Bock (1954) was not applicable here, due to the large amounts of protein present in the precipitate.) Additional acetone was added to bring the final volume to $7 \mathrm{ml}$. The optical density was read on a Klett-Summerson colorimeter with filter no. $\mathbf{5 4}$ $(540 \mathrm{~m} \mu$.). The readings were compared with those obtained from a standard curve, which was prepared by the reduction of TTC with sodium sulphide according to Black \& Speer (1953). A few crystals of sodium sulphide were added to known amounts of TTC (10-100 $\mu \mathrm{g}$.) dissolved in $1 \mathrm{ml}$. distilled water. The reaction was allowed to proceed for $1 \mathrm{hr}$., $1 \mathrm{ml} .10 \%$ TCA solution was then added and the mixture brought to a final volume of $7 \mathrm{ml}$. with acetone. The optical densities were determined on the Klett-Summerson colorimeter using filter no. 54.

Determinations of other enzymic activities were made according to published procedures, and the compositions of the reaction mixtures are given in the table headings and the figure legends.

\section{Demonstration of the presence of enzymic pathways}

Phosphorylase. Homogenates of Paramecium aurelia stock 47.8 contain an active phosphorylase, the presence of which was demonstrated by the method described by Whelan (1955), except that glycogen was substituted for starch. The results are given in Table 2.

The liberation of orthophosphate in the absence of added glycogen is not due to the action of acid phosphatase, because in Paramecium aurelia this enzyme has a low activity at $\mathrm{pH} 6 \cdot 0$ (Fig. 9). Apparently enough stored 
glycogen is present in $\boldsymbol{P}$. aurelia to allow the reaction to proceed in the absence of added glycogen.

Hexokinase. This enzyme was determined by following the reduction of triphosphopyridine nucleotide (TPN) in a reaction mixture containing glucose, a cell-free extract of Paramecium aurelia and an added excess of glucose-6phosphate dehydrogenase, according to the method of Wood \& Schwerdt (1953). A cell-free extract was prepared by centrifugation of a homogenate at $24,000 \mathrm{~g}$ for $15 \mathrm{~min}$. at $4^{\circ}$ in an angle centrifuge. The results are given in Fig. 1.

Table 2. Phosphorylase in homogenates of Paramecium aurelia, var. 4, stock 47.8

The complete reaction mixture contained $0.2 \mathrm{ml} .4 \%(\mathrm{w} / \mathrm{v})$ glycogen solution, $100 \mu$ mole glucose-1-phosphate, $4.0 \mathrm{ml}$. homogenate containing $26.4 \mathrm{mg}$. protein and $0 \cdot 1 \mathrm{M}$-citrate$\mathrm{NaOH}$ buffer to make a total volume of $6 \mathrm{ml}$. $\mathrm{pH} 6 \cdot 0$, temp. $38^{\circ}$.

$\mu$ mole phosphorus liberated/mg. protein

Minutes

\begin{tabular}{|c|c|c|c|c|c|c|}
\hline Reaction mixture & $\mathbf{0}$ & $\mathbf{5}$ & 10 & $\mathbf{3 0}$ & 60 & 120 \\
\hline Complete & 0 & $0 \cdot 003$ & $0 \cdot 012$ & $0 \cdot 036$ & $0 \cdot 079$ & $0 \cdot 136$ \\
\hline Minus glycogen & $0 \cdot 002$ & $0 \cdot 007$ & $0 \cdot 011$ & $0 \cdot 036$ & 0.073 & $0 \cdot 130$ \\
\hline $\begin{array}{l}\text { Minus glucose-1-phosphate } \\
\text { and glycogen }\end{array}$ & $\mathbf{0}$ & 0 & $\mathbf{0}$ & $\mathbf{0}$ & $\mathbf{0}$ & $\mathbf{0}$ \\
\hline Minus homogenate & $\mathbf{0}$ & 0 & 0 & 0 & 0 & 0 \\
\hline
\end{tabular}

Phosphoglucomutase. The presence of this enzyme in homogenates is indicated by the fact that glucose-1-phosphate could also act as substrate for the dehydrogenation by glucose-6-phosphate dehydrogenase (Fig. 1). The transformation of glucose-1-phosphate to glucose-6-phosphate was followed by the decrease in acid-labile phosphate $\left(7 \mathrm{~min}\right.$. hydrolysis in $1.0 \mathrm{x}-\mathrm{HCl}$ at $\left.100^{\circ}\right)$ in a test system described by Najjar (1948) (Fig. 2).

Phosphohexoisomerase. The removal of fructose-6-phosphate from a reaction mixture and the formation of fructose reactive material from glucose-6phosphate provided evidence for the presence of phosphohexoisomerase in homogenates (Sable \& Calkins, 1953) (Fig. 3).

Aldolase. The presence of this enzyme was demonstrated by incubating a homogenate with the $\mathrm{Mg}$-salt of fructose-1:6-diphosphate, using hydrazine as the trapping agent for the trioses formed (Sibley \& Lehninger, 1949; Beck, 1955), and measuring the triosehydrazone by its conversion to the chromogen of the 2,4-dinitrophenylhydrazine derivative. The trapped triosehydrazone was also measured by determining the amount of alkali-labile phosphate formed (Meyerhof \& Lohmann, 1934). The results are given in Table 3.

Triosephosphate dehydrogenase was determined in a reaction mixture containing $\mathbf{M g}$-fructose-1:6-diphosphate, homogenate and TTC. The reduction of TTC indicated the presence of a triosephosphate dehydrogenase (Table 4). The addition of hydrazine blocked the reduction of TTC, presumably by trapping the triose intermediates, and the addition of iodoacetic acid (IOA) prevented the same reaction presumably by inhibiting the triosephosphate dehydrogenase itself. 
Glucose-6-phosphate dehydrogenase and 6-phosphogluconic acid dehydrogenase react specifically with DPN in Paramecium aurelia and the change in absorption at $340 \mathrm{~m} \mu$. with time is a measure of the reaction. An active cell extract was prepared by twice-repeated freezing and thawing of a homogenate. The latter was prepared in a Potter-Elvehjem type homogenizer. The mixture was centrifuged for $30 \mathrm{~min}$. at $850 \mathrm{~g}$ to prepare a cell-free extract. The reaction mixture of Wood \& Schwerdt (1953) was used. The results are given in Fig. 4.

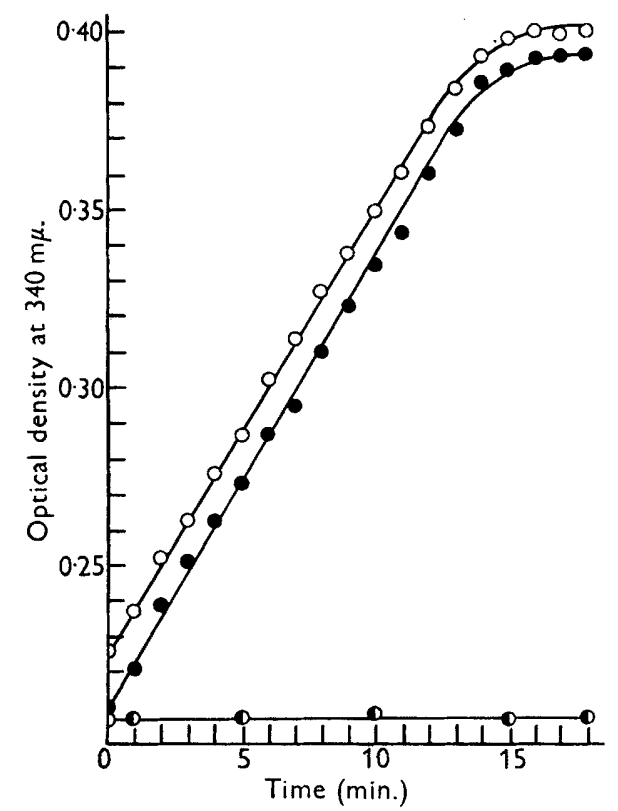

Fig. 1

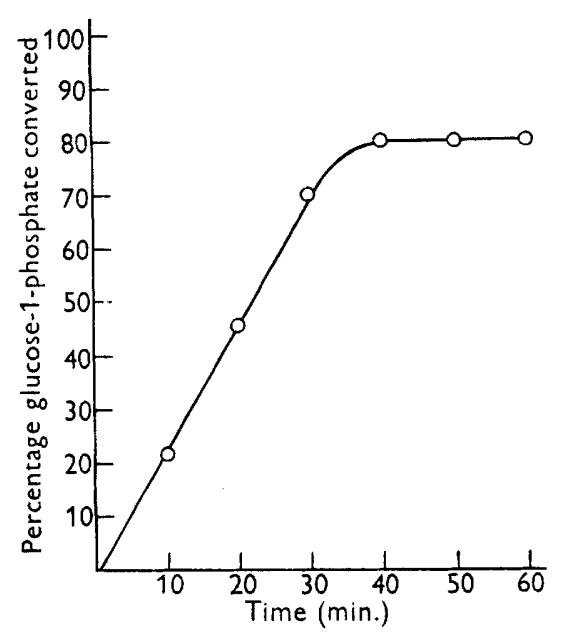

Fig. 2

Fig. 1. Demonstration of the presence of hexokinase in cell-free extracts of Paramecium aurelia. The reaction mixture contained: $0.3 \mathrm{ml}$. cell-free extract (1.8 $\mathrm{mg}$. protein), $5 \mu$ mole $\mathrm{MgCl}_{2}, 50 \mu \mathrm{g}$. TPN (Sigma, $80 \%$ pure), $3 \mathrm{mg}$. glucose-6-phosphate dehydrogenase (Sigma, 0.15 Kornberg units/mg.), 3.3 $\mu$ mole substrate, $0 \cdot 25$ M-glycylglycine buffer ( $\mathrm{pH} \mathrm{7.4)}$ to a final volume of $3 \mathrm{ml}$. The change in optical density at $25^{\circ}$ was determined with a Beckman DU spectrophotometer at $340 \mathrm{~m} \mu$. in cuvettes with $1 \mathrm{~cm}$. light path. $\mathrm{O}-\mathrm{O}$, glucose-1-phosphate;

$$
- \text {, glucose; } \mathbf{O}-\mathbf{O} \text {, no substrate. }
$$

Fig. 2. Phosphoglucomutase activity of homogenates of Paramecium aurelia. The complete test systems consisted of : $3 \mathrm{ml}$. homogenate $(19 \cdot 2 \mathrm{mg}$. protein), $50 \mu$ mole Tris buffer (pH 7.5), $10 \mu$ mole $\mathbf{M g C l}_{2}, 10 \mu$ mole glucose-1-phosphate (Schwarz Laboratories), $50 \mu$ mole cysteine. Total volume $6 \mathrm{ml}$, temp. $32^{\circ}$. Reactions stopped at $10 \mathrm{~min}$. intervals with $5 \mathrm{ml}$. of $6 \%(\mathrm{w} / \mathrm{v})$ perchloric acid and the reaction mixture hydrolysed for $7 \mathrm{~min}$. in $1 \mathrm{~N}-\mathrm{HCl}$ in a boiling water bath. Liberated inorganic phosphate was determined according to Fiske \& SubbaRow (1925). No easily hydrolysable phosphate was detectable in the absence of substrate.

Pentose metabolism. When ribose-5-phosphate was incubated in the presence of a homogenate of Paramecium aurelia, TTC and DPN, reduction of TTC was observed indicating the oxidation of ribose-5-phosphate. Addition of hydrazine prevented the reduction of TTC (Table 5). The course of this oxidation 
could be further analysed with the same reaction mixture using the colour reactions described by Dische \& Borenfreund (1951) and by Mejbaum (1939). An increase in absorption over the range from 450 to $700 \mathrm{~m} \mu$. of the chromogen formed in the Dische-Borenfreund reaction indicated the formation of ketopentose, suggesting the presence of pentosephosphate isomerase (Fig. 5). This

\section{Table 3. The formation of chromogen by trapped triosehydrazone and alkali labile phosphate formed by the action of aldolase}

The reaction mixtures contained: $0.5 \mathrm{ml}$. homogenate $(7.1 \mathrm{mg}$. protein), $12.5 \mu$ mole Mg-fructose-1: 6-diphosphate, $100 \mu$ mole Tris buffer (pH 8.5), $140 \mu$ mole hydrazine sulphate (pH 8.6), final volume $2.5 \mathrm{ml}$, temp. $37^{\circ}$. The reactions were stopped at various time intervals with $2 \mathrm{ml} .10 \%(\mathrm{w} / \mathrm{v})$ trichloroacetic acid and the chromogen developed in a $1 \mathrm{ml}$. sample. The optical density was measured in the Klett-Summerson colorimeter at $540 \mathrm{~m} \mu$. (filter no. 54) against the reaction mixture without substrate as a blank. Alkali labile phosphate was determined on a separate $1 \mathrm{ml}$. sample.

\begin{tabular}{|c|c|c|c|c|}
\hline \multirow{2}{*}{$\begin{array}{c}\text { Time } \\
\text { (min.) }\end{array}$} & \multicolumn{2}{|c|}{$\begin{array}{c}\mu \text { mole alkali labile phosphate } \\
\text { liberated/mg. protein }\end{array}$} & \multicolumn{2}{|c|}{$\begin{array}{l}\text { increase in optical density } \\
\text { of chromogen at } 540 \mathrm{~m} \mu \text {. }\end{array}$} \\
\hline & Experimental & Endogenous & Experimental & Endogenous \\
\hline 10 & $0 \cdot 019$ & - & $0 \cdot 038$ & - \\
\hline 20 & $0 \cdot 039$ & - & $0 \cdot 164$ & - \\
\hline 30 & 0.065 & - & 0.300 & - \\
\hline 40 & 0.093 & - & 0.390 & - \\
\hline 50 & 0.099 & - & $0 \cdot 480$ & - \\
\hline 60 & $0 \cdot 124$ & 0.028 & 0.600 & - \\
\hline
\end{tabular}

Table 4. Triosephosphate dehydrogenase in homogenate of Paramecium aurelia

The complete system contained: $0.5 \mathrm{ml}$. homogenate (10 mg. of protein), $25 \mu$ mole Mg-fructose-1:6-diphosphate, $5 \mu$ mole cysteine, $0 \cdot 1 \mu$ mole DPN, $20 \mu$ mole $\mathrm{K}_{2} \mathrm{HPO}_{4}$, $1.5 \mu$ mole TTC, $70 \mu$ mole Tris buffer ( $\mathrm{pH} \mathrm{7.5),2.5} \mu$ mole $\mathrm{MgCl}_{2}$. $50 \mu$ mole hydrazine or $2 \mu$ mole iodoacetic acid (IOA) were included where indicated-total volume $2 \cdot 0 \mathrm{ml}$., temp. $38^{\circ}$.

\begin{tabular}{lccc} 
& \multicolumn{3}{c}{$\mu$ mole TTC reduced } \\
& $\overbrace{30 \mathrm{~min} .}$ & $60 \mathrm{~min}$. & $90 \mathrm{~min}$. \\
Complete system & 0.037 & 0.054 & 0.088 \\
Complete system plus IOA & - & 0.010 & 0.007 \\
Complete system plus hydrazine & - & $\mathbf{0 . 0 1 9}$ & 0.008 \\
Endogenous & - & 0.017 & 0.024
\end{tabular}

Table 5. Oxidation of ribose-5-phosphate by homogenate of Paramecium aurelia

The reaction mixtures consisted of $14.7 \mu$ mole ribose-5-phosphate, 1.5 $\mu$ mole TTC, $0 \cdot 1 \mu$ mole DPN, $10 \mu$ mole $\mathrm{MgCl}_{2}, 20 \mu$ mole $\mathrm{K}_{2} \mathrm{HPO}_{4}$, homogenate containing $15 \cdot 5 \mathrm{mg}$. protein, $0 \cdot 1 \mathrm{M}$-Tris buffer $(\mathrm{pH} 7 \cdot 6)$ to $3 \cdot 0 \mathrm{ml}$. The reactions were stopped at $15 \mathrm{~min}$. intervals by adding $1 \mathrm{ml} .10 \%$ (w/v) TCA.

$\mu$ mole TTC reduced/mg. protein

Minutes

Complete

\begin{tabular}{ccccc}
\multicolumn{5}{c}{ Minutes } \\
15 & 30 & 45 & 60 & 75 \\
0.026 & 0.046 & 0.054 & 0.068 & 0.073 \\
0.020 & - & - & - & 0.023 \\
- & - & - & - & 0.018
\end{tabular}




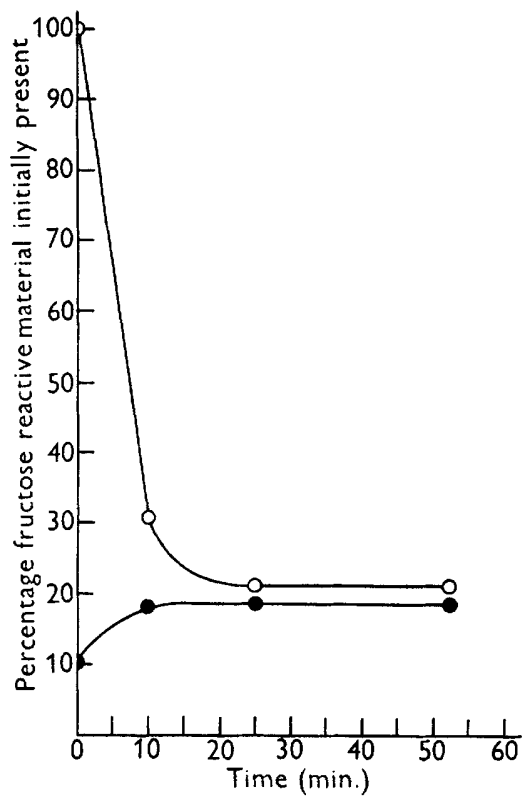

Fig. 3

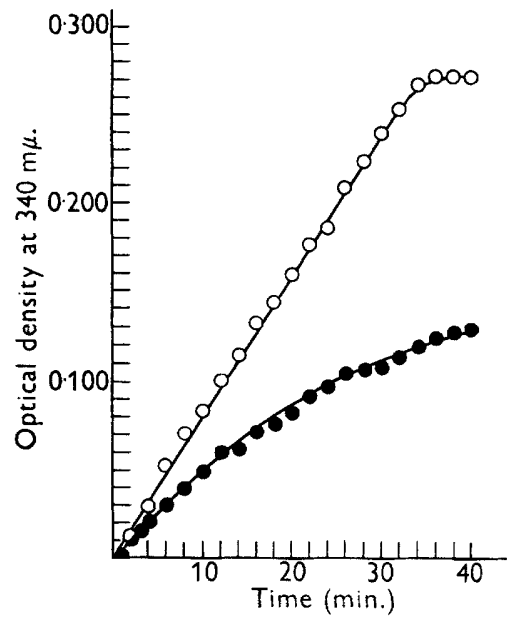

Fig. 4

Fig. 3. Demonstration of the presence of phosphohexoisomerase in homogenates of Paramecium aurelia. The reaction mixture contained $3 \mathrm{ml}$. homogenate $(18.2 \mathrm{mg}$. protein), $10 \mu$ mole substrate (glucose-6-phosphate or fructose-6-phosphate), $50 \mu$ mole Tris buffer (pH 7.5), $10 \mu$ mole $p$-chloromercuribenzoate. Total volume $5 \mathrm{ml}$, temp. $32^{\circ}$. Volumes of $1 \mathrm{ml}$. were removed at intervals, and the reaction stopped by the addition of $5 \mathrm{ml} .6 \%(\mathrm{w} / \mathrm{v})$ perchloric acid. Fructose reactive material in the supernatant after centrifugation was determined according to Roe (1934). In these analyses account was taken of the fact that fructose-6-phosphate gives considerably less colour than an equimolar amount of free fructose. The factor 0.75 was used to correct for this difference. $\bigcirc-O$, fructose-6-phosphate; $\longrightarrow$, glucose-6-phosphate.

Fig. 4. Glucose-6-phosphate dehydrogenase and 6-phosphogluconic acid dehydrogenase in Paramecium aurelia extracts. The medium contained: $\mathbf{3 \cdot 3} \mu$ mole substrate, $25 \mu \mathrm{g}$. DPN (Sigma, $65 \%$ pure), $5 \mu$ mole $\mathrm{MgCl}_{2}$ and $0.25 \mathrm{ml}$. $P$. aurelia extract (1 mg. protein). Tris buffer $(0.1 \mathrm{M}, \mathrm{pH} 7.8)$ to $0.5 \mathrm{ml}$., temp. $27^{\circ}$. The optical density was measured in the Beckman DU spectrophotometer using cells with a light path of $1 \mathrm{~cm}$. The readings were made against the above reaction mixture from which the substrate was omitted. There was no endogenous reduction of DPN. $\bigcirc-O$, glucose-6-phosphate; 6-phosphogluconate.

is further corroborated by an analysis of the orcinol spectra of the reaction mixture at $0 \mathrm{hr}$. and at $2 \mathrm{hr}$. (Fig. 6). Concomitant with the decrease of the aldopentose peak at $670 \mathrm{~m} \mu$. an increase in the ketopentose peak at $540 \mathrm{~m} \mu$. is noted. At the same time aldopentose reactive material disappears from the reaction mixture (Table 6). According to Horecker and co-workers (Horecker, Smyrniotis \& Seegmiller, 1951; Seegmiller \& Horecker, 1952; Horecker, Smyrniotis \& Klenow, 1953), the ratio $\mathrm{D}_{540} / \mathrm{D}_{670}$ for aldopentose is $0 \cdot 19$ and for ribulose 0.90. Similarly, the ratio $D_{670} / D_{580}$ for sedoheptulose is 0.29 and for pentose 3.78. The course of the change of these two ratios is given in Table 7, the results being consistent with the formation of ketopentose and, in addition, 
Table 6. Utilization of aldopentose reactive material by homogenates of Paramecium aurelia

The reaction mixture was identical with that of Fig. 5.

\begin{tabular}{lrrc} 
& \multicolumn{3}{c}{$\mu$ mole of aldopentose } \\
\cline { 2 - 4 } Experimental & 0 min. & 5 min. & 120 min. \\
Endogenous & $18 \cdot 43$ & $17 \cdot 21$ & $11 \cdot 83$ \\
Aldopentose remaining & $2 \cdot 63$ & $2 \cdot 98$ & $4 \cdot 09$ \\
& $15 \cdot 80$ & $14 \cdot 23$ & $7 \cdot 74$
\end{tabular}

Table 7 . Change in $\mathrm{D}_{540} / \mathrm{D}_{670}$ and $\mathrm{D}_{670} / \mathrm{D}_{580}$ ratios during incubation of ribose-5-phosphate with homogenate of Paramecium aurelia

The reaction mixture was identical with that in Fig. 7.

\begin{tabular}{cccccc} 
& \multicolumn{5}{c}{ Minutes } \\
\cline { 2 - 6 } Ratio & 0 & 10 & 30 & 60 & 120 \\
$\mathrm{D}_{540} / \mathrm{D}_{670}$ & $0 \cdot 27$ & $0 \cdot 32$ & $0 \cdot 36$ & $0 \cdot 61$ & $0 \cdot 63$ \\
$\mathrm{D}_{670} / \mathrm{D}_{680}$ & 4.51 & $4 \cdot 17$ & $3 \cdot 61$ & $2 \cdot 11$ & 1.92
\end{tabular}

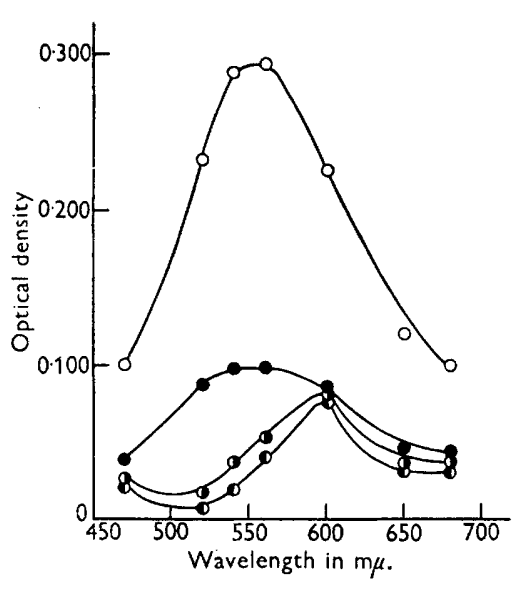

Fig. 5

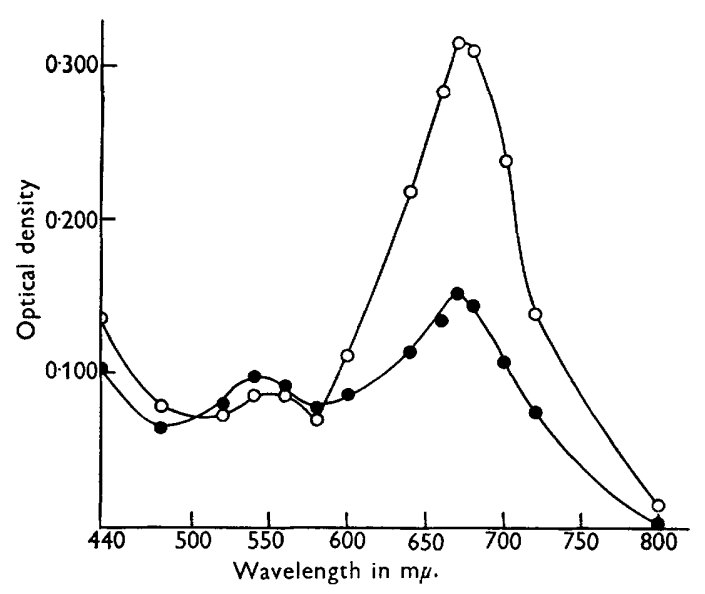

Fig. 6

Fig. 5. Formation of ketopentoses as indicated by the change in absorption spectra. The reaction mixture consisted of $\mathbf{1 5 . 8 0} \mu$ mole ribose-5-phosphate, $375 \mu$ mole Tris buffer (pH $7 \cdot 0$ ) and $27.4 \mathrm{mg}$. homogenate protein in a total volume of $4 \mathrm{mI}$, temp. $27^{\circ}$. $0.5 \mathrm{ml}$. samples were removed at various time intervals and added to $4.5 \mathrm{ml} .10 \%$ TCA $(\mathrm{w} / \mathrm{v})$. $1 \mathrm{ml}$. samples were used for the Dische-Borenfreund reaction and $0.2 \mathrm{ml}$. samples for the orcinol reaction. Absorption spectra were measured in the Beckman DU spectrophotometer in a cell with a $1 \mathrm{~cm}$. light path. - experimental zero time; $\mathrm{O}-\mathrm{O}$, experimental $120 \mathrm{~min}$.; $\mathrm{O}-\mathrm{O}$, endogenous zero time; $\mathrm{O}-\mathrm{O}$, endogenous $120 \mathrm{~min}$.

Fig. 6. Formation of ketopentoses by homogenate of Paramecium aurelia. The curves represent the change in absorption spectra over the range of $440-800 \mathrm{~m} \mu$. of the chromogens formed in the orcinol reaction. The reaction mixture was identical with that of Fig. 5. $\mathrm{O}-\mathrm{O}$, zero time; 
of heptose, as probable intermediates in the oxidation of pentosephosphate. This probability is strengthened by the observation that Paramecium homogenates form pentoses from sedoheptulose. A pentose peak appears in the orcinol spectrum of the reaction mixture (Fig. 7), while at the same time the concentration of sedoheptulose decreases (Fig. 8).

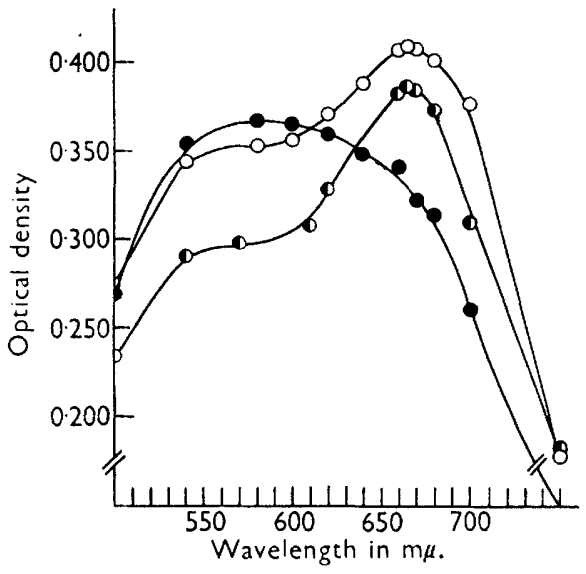

Fig. 7

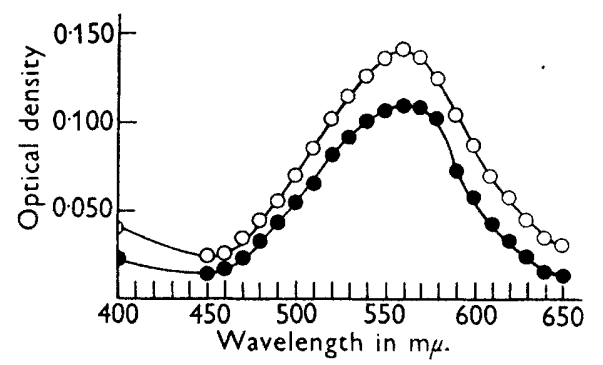

Fig. 8

Fig. 7. Formation of pentoses from sedoheptulose by homogenate of Paramecium aurelia. The curves represent the absorption spectra of the chromogen formed in the orcinol reaction by the sedoheptulose and pentoses. The reaction mixture consisted of $9 \mu$ mole sedoheptulose [kindly furnished by Dr B. L. Horecker as the Ba-salt (78\% pure)], $390 \mu$ mole Tris buffer (pH 7.6), 0.1 mg. cocarboxylase complex (Difco), 2 ml. homogenate $\left(41 \mathrm{mg}\right.$. protein). Final volume $5 \mathrm{ml}$, temp. $37^{\circ} .1 \mathrm{ml}$. samples were removed at various times and added to $4 \mathrm{ml} .10 \%(\mathrm{w} / \mathrm{v})$ TCA. $0.5 \mathrm{ml}$. samples were used for the Dische-Borenfreund and orcinol reactions. -0 , zero time; $\bigcirc-1,60 \mathrm{~min}$.; O-O, $120 \mathrm{~min}$.

Fig. 8. Disappearance of sedoheptulose. The curves represent the absorption by the chromogen of sedoheptulose formed in the Dische-Borenfreund reaction at 0 and at 120 min. The composition of the reaction medium was identical with that of Fig. 7 . $\mathrm{O}-\mathrm{O}, 0 \mathrm{~min}$; $0-120 \mathrm{~min}$.

Enzymes of the citric acid cycle. Of the tricarboxylic acid cycle acids, citric acid, isocitric acid, $\alpha$-ketoglutaric acid, succinic acid, malic acid and glutamic acid can be oxidized by homogenates of Paramecium aurelia in the presence of DPN or TPN and TTC. The results are given in Table 8.

Since TTC is a sluggish electron acceptor, the oxidation of succinic acid and of $\alpha$-ketoglutaric acid by homogenates was measured manometrically following the method of Eisenberg (1953). It can be seen from Table 9 that the oxidation of these two acids proceeds faster when other electron acceptors are used.

Fumarase. The presence of this enzyme was demonstrated by measuring the increase in optical density at $240 \mathrm{~m} \mu$. (Racker, 1950) due to the appearance of the double bond of fumaric acid in a reaction mixture containing malic acid and a homogenate. The fumarase activity was mostly found in the non-sedimentable fraction (at 10,000 $\mathrm{g}$ for $30 \mathrm{~min}$.) of the homogenate (Table 10). This 


\section{Table 8. Oxidation of citric acid cycle intermediates by Paramecium homogenates}

The reaction mixtures contained $10 \mu$ mole substrate, $1 \mu$ mole DPN or $0.3 \mu$ mole TPN, $5 \mu$ mole cysteine, $10 \mu$ mole $\mathrm{MgCl}_{2}, 10 \mu$ mole TTC, $150 \mu$ mole Tris buffer (pH 7.4), $1 \mathrm{ml}$. Paramecium homogenate $\left(9.7 \mathrm{mg}\right.$. protein). Total volume $2 \mathrm{ml}$.; gas phase air; temp. $37^{\circ}$. Identical reaction mixtures were treated as described in the text at zero time, 30 and $60 \mathrm{~min}$.

\begin{tabular}{lcc} 
& \multicolumn{2}{c}{$\mu$ mole TTC reduced } \\
\cline { 2 - 3 } \multicolumn{1}{c}{ Substrate } & $30 \mathrm{~min}$. & $60 \mathrm{~min}$. \\
Citric acid & 0.08 & 0.29 \\
Isocitric acid & 0.43 & 0.46 \\
$\alpha$-Ketoglutaric acid & 0.004 & 0.008 \\
Succinic acid & 0.03 & 0.05 \\
Malic acid & $0 \cdot 19$ & 0.31 \\
Glutamic acid & 0.11 & $0 \cdot 19$ \\
Endogenous & 0.002 & 0.006
\end{tabular}

Table 9. Oxidation of $\alpha$-ketoglutarate and succinate by homogenate of Paramecium aurelia

The reaction medium for the determination of the oxidation of $\alpha$-ketoglutarate by homogenates contained $10 \mu$ mole substrate, $50 \mu$ mole Tris buffer $(\mathrm{pH} \mathrm{7.3}), 5 \mu$ mole $\mathrm{MgCl}_{2}$, $0.5 \mathrm{mg}$. DPN, $10 \mu$ mole methylene blue, 3.5 Lipmann units of CoA and $0.5 \mathrm{ml}$. homogenate (4.6 $\mathrm{mg}$. protein). The reaction medium for the determination of the oxidation of succinate contained $10 \mu$ mole substrate, $50 \mu$ mole phosphate buffer (pH 7.3), 0.6 $\mu$ mole cytochrome $c$ (Sigma), and $0.5 \mathrm{ml}$. homogenate (4.6 mg. protein). For both determinations: final volume $1 \mathrm{ml}$; gas phase air; temp. $32^{\circ} ; 0.2 \mathrm{ml} .10 \% \mathrm{KOH}(\mathrm{w} / \mathrm{v})$ in the centre well.

\begin{tabular}{|c|c|c|}
\hline \multirow[b]{2}{*}{ Substrate } & \multicolumn{2}{|c|}{$\mu$ mole $\mathrm{O}_{2} / \mathrm{mg}$. protein } \\
\hline & $30 \mathrm{~min}$. & $60 \mathrm{~min}$. \\
\hline$\alpha$-Ketoglutarate & $3 \cdot 7$ & $6 \cdot 2$ \\
\hline Succinate & $1 \cdot 1$ & $1 \cdot 8$ \\
\hline Endogenous & $0 \cdot 1$ & $0 \cdot 2$ \\
\hline
\end{tabular}

\section{Table 10. Distribution of fumarase activity in homogenates of Paramecium aurelia}

The reaction mixture consisted of $25 \mu$ mole malate $(\mathrm{pH} 7 \cdot 4), 125 \mu$ mole Tris buffer (pH 7.5), homogenate preparation 0.1 to $0.5 \mathrm{ml}$. as required. Total volume $3 \mathrm{ml}$. The increase in optical density at $240 \mathrm{~m} \mu$. was measured with the Beckman DU spectrophotometer. The original homogenate was centrifuged in a Sorvall SS-1 angle centrifuge at $10,000 \mathrm{~g}$ for $\frac{1}{2} \mathrm{hr}$. at room temperature. A measured volume of the supernatant was used for the determination of the fumarase activity. The sediment was taken up in $10 \mathrm{ml}$. Tris buffer $(0 \cdot 1 \mathrm{M}, \mathrm{pH} 7 \cdot 4)$ and the fumarase activity was determined on a measured volume.

\begin{tabular}{|c|c|c|c|c|c|c|}
\hline Fraction & $\begin{array}{c}\text { Total } \\
\text { volume } \\
\text { (ml.) }\end{array}$ & $\begin{array}{l}\text { Protein/ml. } \\
\text { (mg.) }\end{array}$ & $\begin{array}{c}\text { Total } \\
\text { protein } \\
\text { (mg.) }\end{array}$ & Units*/ml. & $\begin{array}{l}\text { Total } \\
\text { units }\end{array}$ & $\begin{array}{l}\text { Specific } \\
\text { activity }\end{array}$ \\
\hline $\begin{array}{l}\text { Original homo- } \\
\text { genate }\end{array}$ & 6 & $10 \cdot 81$ & $64 \cdot 86$ & $133 \ddagger$ & 798 & $12 \cdot 3$ \\
\hline Sediment & 10 & $5 \cdot 59$ & $55 \cdot 9$ & 14 & 140 & $2 \cdot 5$ \\
\hline Supernatant & $3 \cdot 1$ & $2 \cdot 86$ & $8 \cdot 9$ & 43 & $133 \cdot 3$ & $14 \cdot 97$ \\
\hline
\end{tabular}

* One unit equals the amount of enzyme causing an increase in optical density of 0.001 per min.

$\dagger$ Specific activity equals number of units per mg. of protein.

\$ Activity determined on a 1:10 (v/v) dilution of the whole homogenate. 
distribution is similar to that found in human liver (Shepherd, Li, Mason \& Ziffren, 1955).

Phosphatase activity was measured at both acid and alkaline $\mathrm{pH}$ values using Na-phenolphthalein phosphate as substrate (Huggins \& Talalay, 1945). Phosphatase activity could only be detected in the acid range, with an optimum activity at $\mathrm{pH} 4.5$ (Fig. 9).

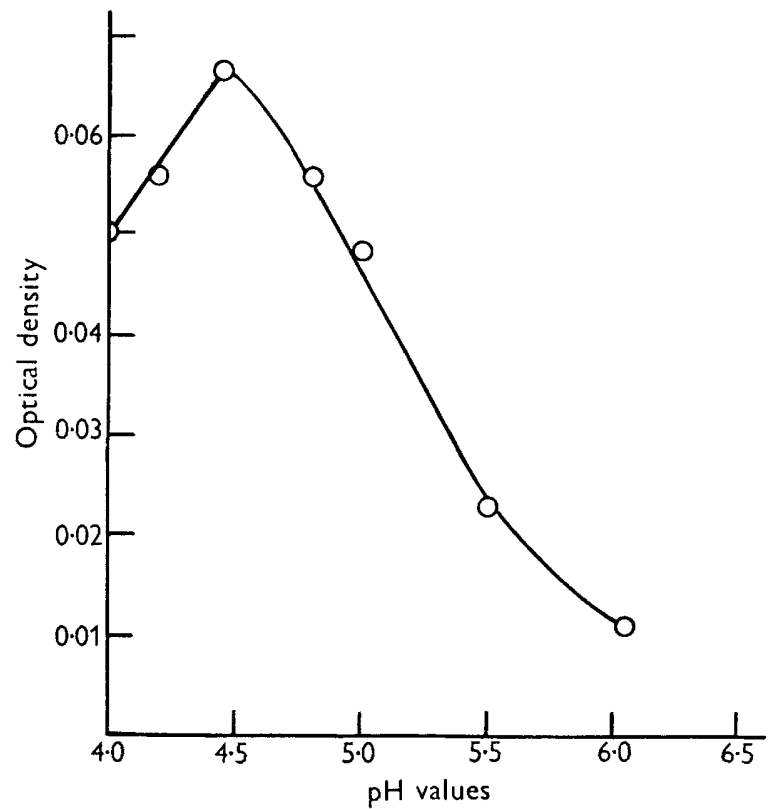

Fig. 9. Effect of $\mathrm{pH}$ value on activity of acid phosphatase in homogenate of Paramecium aurelia. The reaction mixtures consisted of: $5 \mu$ mole Na-phenolphthalein phosphate, $0.3 \mathrm{mg}$. homogenate protein, $0.1 \mathrm{~m}-\mathrm{Na}$ acetate buffer to $5 \mathrm{ml}$. pH adjusted to desired value with $0 \cdot 1 \mathrm{~N}-\mathrm{HCl}$. Temp. $38^{\circ}$. The reactions were stopped with $1 \mathrm{ml} .1 \mathrm{~N}-\mathrm{NaOH}$ after 60 min., and the liberated phenolphthalein measured in the Klett-Summerson colorimeter using filter no. $\mathbf{5 4}$.

\section{DISCUSSION}

The quantitative aspects have not been stressed in this exploratory study. The picture that emerges from this investigation is that of a conventional metabolic pattern. Paramecium aurelia, var. 4, stock 47.8 (sensitive) can metabolize carbohydrates via the three main routes, the glycolytic, the citric acid cycle and the pentosephosphate pathways. Which of the two oxidative schemes, the citric acid cycle or the pentosephosphate pathway, is preferentially utilized has not been determined. An attractive postulate, which is at present under investigation, is that the three pathways are of equal importance for the organism, the glycolytic and citric acid pathways providing the required energy, and the pentosephosphate pathway serving mainly to supply the organism with pentoses. The pentose demand can conceivably be very high in view of the large amount of genetic material carried by $\boldsymbol{P}$. aurelia, specifically in the macronucleus (Moses, 1950). The presence of pentosephosphate iso- 
merase, transaldolase and transketolase has not been unequivocally proven, but the circumstantial evidence for the participation of these enzymes in the pentosephosphate pathway is strong. The reduction of TTC with ribose-5phosphate as substrate and the formation of ketopentose reactive material from added ribose-5-phosphate are indicative of the presence of pentosephosphate isomerase. Similarly, the formation of pentoses from sedoheptulose-7-phosphate is evidence for the establishment of an equilibrium in which transketolase and transaldolase are participating enzymes.

Levine (1955) reported some enzymic studies carried out with Paramecium aurelia, var. 4 , stock 51.8 (sensitive) and $P$. aurelia, var. 8 , stock 135.15 (sensitive). His results are in several aspects at variance with those reported here. Levine was not able to demonstrate the first two steps in the pentosephosphate pathway, the oxidation of glucose-6-phosphate and the oxidation of 6-phosphogluconate. It was suggested that this apparent absence of the oxidative pathway for the utilization of glucose-6-phosphate was due to the availability of pentoses from the 'rather opulent diet the bacteria provide'. If this were the case, the presence of the pentosephosphate pathway in axenically cultured $\boldsymbol{P}$. aurelia could be considered to be an adaptation to the environment. Another explanation, e.g. that there is a difference in enzymic make-up between different stocks, is plausible, although Levine was unable to find such differences between his two stocks.

Seaman (1955) states: 'Although purity of the culture and the availability of chemically defined media are prerequisites for growth and nutrition experiments, these considerations are not of prime importance in purely metabolic studies. If a protozoan can be cultured whatever the complexity of the medium-even with the presence of bacterial contaminants-it is eligible for investigation.' Our studies, however, again emphasize the importance of axenic cultures for biochemical and physiological studies of protozoa, although this emphasis might be tempered by the question: 'How many of the findings, biochemical, nutritional, or even genetic, can be ascribed to adaptation to environmental changes from a natural habitat, via dixenic to axenic cultures?' Only further investigations might provide the answer.

This work was carried out under the auspices of a grant from the National Cancer Institute of the National Institutes of Health (no. C-2160(c)- ), a contract between the Office of Naval Research, Department of the Navy and the Research Division of the Indiana University Foundation (no. NR 135-274), a grant from the National Science Foundation and grants from the Rockefeller Foundation and Indiana University. Partly based on a thesis presented by one of us (D.A.V., Jun.) in partial fulfilment of the requirements for the Ph.D. degree by the Indiana University. One of us (W. B. J.) was a post-doctoral research fellow of the National Cancer Institute of the National Institutes of Health 1955-56).

\section{REFERENCES}

BECK, W. S. (1955). Determination of triosephosphates and proposed modifications in the aldolase method of Sibley and Lehninger. J. biol. Chem. 212, 847.

Black, M. M. \& Speer, F. D. (1953). Relative dehydrogenase activity of kidney and liver slices from control and tumor mice. Proc. Soc. exp. Biol., N.Y. 82, 289. 
Boell, E. J. (1945). Respiratory enzymes in Paramecium: 1. Cytochrome oxidase. Proc. nat. Acad. Sci., Wash. 31, 396.

Brüell, D., Holter, H., Linderstrøm-Lang, D. \& Rozits, K. (1947). A micromethod for the determination of total nitrogen (accuracy $0.005 \mu \mathrm{g} . \mathrm{N}$ ). Biochim. biophys. Acta, 1, 101.

Clark, A. M. (1945). The effect of cyanide and carbon monoxide on the oxygen consumption of Paramecium caudatum. Aust. J. exp. Biol. med. Sci. 23, 317.

Conner, R. L. \& Wagtendonk, W. J. van (1953). Steroid requirements of Paramecium aurelia. J. gen. Microbiol. 12, 31.

Dische, Z. \& Borenfreund, E. (1951). A new spectrophotometric method for the detection and determination of keto sugars and trioses. J. biol. Chem. 192, 583.

Eisenberg, M. A. (1953). The tricarboxylic acid cycle in Rhodospirillum rubrum. J. biol. Chem. 203, 815 .

Fiske, A. \& SubbaRow, Y. (1925). The colorimetric determination of phosphorus. J. biol. Chem. 66, 375.

Geddes, M. \& Humphrey, G. R. (1951). Glycolysis in Paramecium caudatum. Aust. J. exp. med. Sci. 29, 187.

Gornali, A. G., Bardawill, C. J. \& David, M. M. (1949). Determination of serum proteins by means of the biuret reaction. J. biol. Chem. 177, 751 .

Green, D. E., Mir, S., Mahler, H. R. \& Bock, R. M. (1954). Studies on the fatty acid oxidizing system of animal tissues. III. Butyryl coenzyme A dehydrogenase. J. biol. Chem. 206, 1.

Horecker, B. L., Smyrniotis, P. Z. \& Klenow, H. (1953). The formation of sedoheptulose phosphate from pentose phosphate. J. biol. Chem. 205, 661 .

Horecker, B. L., Smyrniotis, P. Z. \& Seegmiller, J. E. (1951). 'The enzymatic conversion of 6-phosphogluconate to ribulose-5-phosphate and ribose-5phosphate. J. biol. Chem. 193, 383.

Huggins, C. \& Talalay, P. (1945). Sodium phenolphthalein phosphate as a substrate for phosphatase tests. J. biol. Chem. 159, 399.

Humphrey, B. A. \& Humphrey, G. T. (1948). Studies in the respiration of Paramecium caudatum. J. exp. Biol. 25, 123.

Katzberg, A. A. (1950). A micromacerator. Science, 112, 339.

Levine, M. (1955). An enzymatic comparison of two interbreeding but genetically isolated varieties of Paramecium aurelia. J. cell. comp. Physiol. 45, 409.

Mejbaum, W. (1939). Über die Bestimmung kleiner Pentosemengen, insbesondere in Derivaten der Adenylsäure. Z. physiol. Chem. 258, 117.

Meyerhof, O. \& LohmanN, K. (1934). Über die enzymatische Gleichgewichtsreaktion zwischen Hexosediphosphorsäure und Dioxyacetonphosphorsäure. Biochem. Z. $271,89$.

Miller, C. A. \& Wagtendonk, W. J. van (1956). The essential metabolites of a strain of Paramecium aurelia (stock 47.8 ) and a comparison of the growth rate of different strains of Paramecium aurelia in axenic culture. J. gen. Microbiol. $15,280$.

Moses, M. J. (1950). Nucleic acids and proteins of the nuclei of Paramecium. J. Morph. 87, 498.

NaJjar, V. A. (1948). The isolation and properties of phosphoglucomutase. J. biol. Chem. 175, 281.

RACKER, E. (1950). Spectrophotometric measurements of the enzymatic formation of fumaric and cis-aconitic acid. Biochim. biophys. Acta, 4, 211.

Roe, J. H. (1934). A colorimetric method for the determination of fructose in blood and urine. J. biol. Chem. 107, 15.

Sable, H. Z. \& Calkins, C. W. Jun. (1953). Phosphoglucomutase and phosphohexoseisomerase in Tunicates. J. biol. Chem. 204, 695.

Sato, T. \& Tamiya, H. (1937). Über die Atmungsfarbstoffe von Paramecium. Cytologia, Tokyo (Suppl. part 2), p. 1133. 
Seaman, G. R. (1955). Metabolism of free-living ciliates. In Biochemistry and Physiology of Protozoa, 2, 91. New York: Academic Press Inc.

Seegmiler, J. E. \& Horecker, B. L. (1952). Metabolism of 6-phosphogluconic acid in liver and bone marrow. J. biol. Chem. 194, 261.

Shepherd, J. A., Li, Y. W., Mason, E. E. \& ZifFren, S. E. (1955). The distribution of aconitase and fumarase in homogenates of human liver. J. biol. Chem. 213, 405.

Sibley, J. A. \& Lehninger, A. L. (1949). Determination of aldolase in animal tissues. J. biol. Chem. 177, 859.

Simonsen, D. H. \& WAgtendonk, W. J. van (1952). Respiratory studies on Paramecium aurelia, variety 4 , killers and sensitives. Biochim. biophys. Acta, 9, 515.

Simonsen, D. H. \& Wagtendonk, W. J. van (1956). The succinoxidase system of killer and sensitive stocks of Paramecium aurelia, variety 4. J. gen. Microbiol. $15,39$.

Vloemman, D. A. (1955). Enzymological studies on Paramecium aurelia, variety 4, stock 47.8, sensitive. Ph.D. Thesis, Indiana University.

Wagtendonk, W. J. van, Conner, R. L., Miller, C. A. \& Rao, M. R. R. (1953). Growth requirements of Paramecium aurelia, variety 4, stock 51.7, sensitives and killers in axenic medium. Ann. N.Y. Acad. Sci. 56, 929.

Wagtendonk, W. J. van, Simonsen, D. H. \& Zirl, L. P. (1952). The use of electromigration techniques in washing and concentrating cultures of Paramecium aurelia. Physiol. Zoöl. 25, 312.

Whelan, W. J. (1955). Methods in Enzymology. Ed. S. P. Colowick \& N. O. Kaplan, 1, 192. New York: Academic Press Inc.

Wood, W. A. \& Schwerdt, R. F. (1953). Carbohydrate oxidation by Pseudomonas fluorescens. I. The mechanism of glucose and gluconate oxidation. J. biol. Chem. 201, 501. 